\title{
Black Generation Y Students' Attitudes towards Web Advertising Value
}

\author{
Professor, Ayesha Lian Bevan-Dye \\ North-West University (Vaal Triangle Campus) \\ E-mail: ayeshabevandye@gmail.com or Ayesha.Bevandye@nwu.ac.za
}

\section{Doi:10.5901/mjss.2013.v4n2p155}

\begin{abstract}
:
The study reported on in this article sought to determine black Generation Y students' attitudes towards Web advertising value. The black Generation Y cohort (individuals born between 1986 and 2005) represent 84 percent of the country's Generation $Y$ and 33 percent of the total population, yet their consumer behaviour remains largely under researched. A structured, self-administered questionnaire was used to gather data on attitudes towards Web advertising value and the value antecedents of informativeness, entertainment, irritation, consumer benefits and credibility from a sample of 400 black Generation Y students across four South African public registered higher education institutions' campuses situated in the Gauteng province. Data analysis included z-tests, Pearson's ProductMoment correlation and regression analysis. The findings suggest that in South Africa, black Generation Y students have a positive attitude towards the value of Web advertising and that the informativeness and consumer benefits antecedents are particularly important predictors of this perceived value.
\end{abstract}

Keywords: Web advertising value antecedents, South Africa, black Generation Y students

\section{Introduction}

Advances in information and communication technologies have given rise to exciting new advertising media channels such as social network site advertising, mobile advertising and Web advertising. Of the three, Web adverting is the most established. As the number of Internet users continues to grow (Internet World Stats, 2012), more and more marketers are adding the Web into their marketing communication mix (Magnaglobal, 2013), making Web advertising an important source of consumer information (Cheng, Blankson, Wang \& Chen 2009).

While worldwide television remains dominate as the primary advertising media for many marketers, the Web is fast becoming the number two channel, often at the expense of radio and print media (Magnaglobal, 2013). Globally, Web advertising exceeded USD100 billion in 2012 and is expected to grow by 15.1 percent in 2013 to reach a forecasted USD118.4 billion (eMarketer, 2013). This growing popularity of the Web as an advertising vehicle is echoed in the South African market, where Web advertising spend grew by 26 percent between March 2010 and March 2011, compared to 23 percent for television advertising, and 11.2 percent for print advertising, albeit from a lower base (Boyle, 2011). Contributing to this growth in Web advertising expenditure is the advent of new formats such as video and more channels such as social networking sites and mobile telephony (eMarketer, 2011). Indeed, in South Africa, the upsurge in Internet users and usage is largely the result of the rapid uptake of mobile devices such as smart phones, $3 G$ modems and tablets (Masote, 2012). Compared to the estimated 6 million desktop Internet users, South Africa has approximately 32 million Internet-capable mobile devices, of which 14 million are using Web services actively (Maake, 2012). Even though the costs of and access to the Internet remain high in South Africa, it is estimated that by 2016 two out of three citizens will be online (de Lanerolle, 2012). In addition, while South Africa lags behind the rest of the world in adopting online shopping (Mzekandaba, 2012), there has been a recent uptake in online shopping (Fairweather, 2012). The growth in Internet usage in South Africa has mostly been amongst the black Africans (Avusi Media Live, 2011) and the country's Internet community mostly comprises black Africans between 15 and 34 years of age with a high school education (de Lanerolle, 2012).

Attitudes towards general advertising in specific media vehicles influence the effectiveness of advertising and this has important implications to the advertising industry in terms of media spending allocation (Ducoffe, 1996; Cheng et al., 2009; Wang \& Sun, 2010; Taylor, Lewin \& Strutton, 2011). A requisite element of the marketing communication strategy is closely matching a specific medium's audience profile with the targeted audience's profile, thereby ensuring that the 
targeted audience is exposed to the marketing message (Schiffman, Kanuk \& Wienblit, 2010). According to Ducoffe (1996), the effective use of the Web as an advertising medium requires an understanding of target audiences' attitudes towards the value of the Web as a source of consumer information, as this will influence their attitudes towards individual advertisements within this medium.

Characterised as being techno-savvy, Generation Y (individuals born between 1986 and 2005) (Markert, 2004) are the first generation to be brought up in the Internet age and constitute an important target audience for Web advertisements (Brackett \& Carr, 2001; Shaw \& Fairhurst, 2008). In South Africa, the African portion of the Generation Y cohort (hereafter referred to as black Generation $Y$ ) is a particularly attractive market segment as it accounts for an estimated 84 percent of the country's Generation Y cohort (Statistics South Africa, 2011) and is an important target audience for Web advertising.

\section{Problem statement}

While several studies on Web adverting attitudes have been undertaken over the years (Ducoffe, 1996; Brackett \& Carr, 2001; Wolin \& Korgaonkar, 2003; Wang \& Sun, 2010) in developed countries, there is a lack of published research on South African's attitudes towards the value of Web advertising, particularly not on the attitudes held by the significantly sized black Generation Y market segment. As such, this study investigates black Generation Y students' attitude towards Web advertising value and its antecedents of informativeness, entertainment, irritation (Ducoffe, 1996), credibility (Brackett \& Carr, 2001) and consumer benefits. In addition, the study investigates black Generation Y students' ranking of the informativeness of advertising in different media, together with the extent to which they perceive advertisements in different media as being representative of their specific age and ethnic cohort.

The decision to focus on students was deliberate and based on the assumption that a tertiary qualification increases an individual's future earning potential (Loudon \& Della Bitta, 1993; Mowen, 1993; Schiffman et al., 2010; Taskinsoy, 2012) and a higher social class status (Schiffman et al., 2010). This, in turn, translates into graduates being likely trendsetters who, potentially, will influence the perceptions, beliefs, attitudes and consumer behaviour of the wider black Generation Y cohort.

\section{Antecedents of Web advertising value}

Ducoffe (1996) defines advertising value as the overall worth of advertising to the consumer and propose informativeness, entertainment and irritation as the antecedents of that value. One of the primary purposes of advertising is to provide consumer information in order to facilitate awareness and knowledge of products, services, organisations and/or ideas (Kotler, 2003). Timely and accurate information leads to informed consumer decision making and increases the likelihood of post-purchase satisfaction (Ducoffe, 1996; Blackwell, Miniard \& Engel, 2006). This informational role is what justifies the very existence of advertising and, according to Wang, Sun, Lei and Toncar (2009), fulfilling this informational role constitutes the primary function of Web advertising. In this role, Web advertising offers several advantages over traditional media. The Web provides fast and convenient access to information on an increasing range of local and global products and services (Ducoffe, 1996). Web keyword advertising ensures that marketing messages are targeted at users when they are searching for information on particular products or services, thereby enhancing the relevance of the advertising information (Ducoffe, 1996; Wu, Lin \& Lin, 2011). Furthermore, the flexibility of Web advertising enables fast and frequent updating of information contained therein (Ducoffe, 1996).

The entertainment value of advertising involves the hedonic pleasure consumers experience when exposed to an advertisement (Korgaonkar, Silverblatt \& O'Leary, 2001; Wang \& Sun, 2010) and is a salient element in emotionally involving consumers with marketing messages thereby influencing the effectiveness of the advertisement (Wang \& Sun, 2010). The multimedia, interactive capabilities of Web advertising serve to increase the potential enjoyment experienced, which, in turn, contributes to the formulation of a positive attitude (Korgaonkar et al., 2001; Carlson \& O'Cass, 2011).

Conversely, advertisements may be viewed as irritating and an unwelcome disruption in the consumer's consumption of a particular medium's content. Ducoffe (1996) indicates that this sense of irritation relates to advertisements employing techniques that annoy, offend or insult individuals, or that appear to be overly manipulative. In addition, advertisements that confuse consumers or that are misleading are likely to be considered irritating and contribute towards a negative attitude conceptualisation (Ducoffe, 1996; Cheng et al., 2009; Prendergast, Liu \& Poon, 2009). Taylor et al., (2011) add that while consumers are accustomed to the idea of exposure to advertising in traditional 
media in exchange for receiving free or subsidised programming and content, the same does not hold true on the Web where advertising is considered an invasive interruption of their online activities.

Web advertising offers several advantages over other media in terms of consumer decision-making benefits making consumer benefits an important antecedent to attitudes towards Web advertising value. Not only do consumers have convenient 24/7 access to up-to-date information on a global array of new and existing products and services on the Web, they can also employ shopping bots to help them track down the best prices and to make informed brand comparisons (Schiffman et al., 2010). As a medium, the Web empowers consumers and enhances their consumer decision-making capabilities.

According to Pollay and Mittal (1993), consumer distrust of and cynicism towards advertisements impedes the credibility of advertising. Brackett and Carr (2001) assert that credibility is a salient antecedent of attitude towards Web adverting value. Consumers assess an advertising message within the context of the medium through which it is presented (Ducoffe, 1996; Prendergast et al., 2009). Hence, a medium's reputation can either enhance or detract from the perceived trustworthiness and believability of advertising messages placed in that media (Schiffman et al., 2010). The Web enables self-publishing and is a largely unregulated environment, which may account for findings indicating that Web advertising is perceived as less credible than other media vehicles (Prendergast et al., 2009).

The Ducoffe (1996) study, which focused on a judgement sample of respondents familiar with advertising on the Web, found that respondents rated Web advertising as somewhat valuable, more informative than entertaining and not particularly irritating, and that informativeness and entertainment positively relate to Web advertising value and irritation negatively. In comparison, the Brackett and Carr (2001) study focusing on college students found that respondents rated Web advertising as less valuable, informative, entertaining and more irritating than those in the Ducoffe (1996) study did. Brackett and Carr (2001) found that Ducoffe's (1996) antecedents of informativeness, entertainment and irritation, together with the antecedent of credibility had a significant relationship to the dependent variable of Web advertising value. Consistent with these two studies, a more recent study found the antecedents of informativeness, entertainment and credibility as significant predictors of attitude towards Web advertising (Wang \& Sun, 2010).

In terms of the relative information value of Web advertising, findings from the Ducoffe (1996) study indicate that the Web was ranked in fifth place just above outdoor media, with television ranked first followed by newspapers, magazines, direct mail and radio. In contrast, Brackett and Carr's (2001) student sample ranked television in first place, followed by newspapers/magazines but Web advertising achieved third place tied with radio. In addition, this student sample predicted that the Web would replace television as the number one ranked source of valuable advertising information in the future.

Another salient aspect in advertising media evaluation is the congruency between the target audience and individuals depicted in the media (Wolburg \& Pokrywczynski, 2001).

\section{Generation $Y$}

Generational cohort research is based on the premise that each generation experiences a shared unique combination of situational and environmental forces that are prevalent during their formative years, and that these shape their perceptions, attitudes and behaviour, and distinguishes them from other generations (Bakewell \& Mitchell, 2003; Twenge \& Cambell, 2008). While generation studies acknowledge that members of older generations alive today are influenced by the same forces that shape younger generations (Nicholas, Rowlands, Clark \& Williams, 2011), they strive to describe how the average individual in younger generations differ from the average individual in older generational cohorts (Twenge \& Cambell, 2008). There is some confusion in the literature regarding the precise start and end dates of Generation Y (Markert, 2004). Some have defined this cohort as individuals born between 1980 and 1994 (Kumar \& Lim, 2008), others as individuals born between 1977 and 1994 or between 1982 and 2000 (Schiffman et al., 2010) and still others as between 1980 and 2003 (Hurst \& Good, 2009).

Markert (2004) suggests using 20-year increments in defining generational cohorts, which, based on Baby Boomers being defined as those born between 1946 and 1965, and Generation X as those born between 1966 and 1985 , places Generation Y as individuals born between 1986 and 2005. In 2013, this would include those aged between 9 and 28 years old. Working within the categorical parameters used to report population counts in South Africa, in 2011 Generation $Y$ was estimated to account for approximately 40 percent of South Africa's population of 50586757 people. Members of the black Generation $Y$ cohort accounted for 33 percent of the total South African population and a staggering 84 percent of South Africa's Generation Y population (Statistics South Africa, 2011). 
Individuals classified as being part of the Generation $Y$ cohort have grown up in a world dominated by the Internet, mobile technologies (Nicholas et al., 2011) and global media (Durvasula \& Lysonski, 2008), which has led to them being more informed, more connected and more technologically literate than any previous generation (Autry \& Berge, 2011).

From instant text messaging, email, virtual social networking to podcasting and the Web, this generation is in constant contact with friends and family, has constant access to entertainment and up-to-date information, and is constantly exposure to media, including marketing messages (Durvasula \& Lysonski, 2008). Their socialisation into a media-saturated world (Wolburg \& Pokrywczynski, 2001; Bakewell \& Mitchell, 2003; Bakewell, Mitchell \& Rothwell, 2006) has made them astute consumers (Rahman \& Azhar, 2010), who are sceptical of marketing messages (Newborne \& Kerwin, 1999; Wolburg \& Pokrywczynski, 2001) and aware of marketing hype (Rahman \& Azhar, 2010).

The Web represents the Generation $Y$ cohort's habitat, the place where they congregate, interact with others, learn, play, work (Spero \& Stone, 2004) and shop (Nicholas et al., 2011), and the place that they turn to first for information (Schwalbe, 2009). This digital environment is a fundamental departure from the world that their parents experienced growing up (Autry \& Berge, 2011). While they do not necessarily purchase online, Generation Y members do utilise the Web in their purchase decision-making process (Spero \& Stone, 2004; Foscht, Schloffer, Maloles \& Chia, 2009), making it an important advertising channel for those marketers targeting this cohort.

In South Africa, commercial and public Internet access came about in late 1993, followed by access to mobile telephony in mid-1994. In addition, 1994 marked the first democratic elections in South Africa. Taken together, Generation $Y$ is the first South African generation to grow up not only in the digital age but also in the post-apartheid era two forces that serve to widen the divergence between this generation and previous generations.

As the first generation to be raised in post-apartheid South Africa, the black Generation Y cohort enjoys several advantages over previous African generations, which include educational, employment and wealth accumulation opportunities. Political transformation policies aimed at uplifting of the previously disadvantaged have led to a rapidly increasing black middle class (Jones, 2007), labelled Black Diamonds (Jones, 2007; Olivier, 2007; de Waal, 2008), who are characterised as being optimistic, self-confident, education-directed and highly ambitious (Olivier, 2007). These Black Diamonds represent important aspirational role models to the black Generation Y cohort and are, most likely, the social class to which black Generation Y students will belong in the future (Bevan-Dye \& Surujlal, 2011), given the link between having a tertiary education and wealth creation (Shevel, 2011).

\section{Research Methodology}

\subsection{Sample}

The study's sampling frame comprised a list of the 28 campuses of the public South African higher education institutions (HEls) situated in the Gauteng province of South Africa. The Gauteng province was selected over the other South African provinces because it contains the highest percentage of the South Africa's 23 public HEls and the highest percentage (31\%) of these institutions' 91 campuses (Note: certain HEls have more than one campus, which may be located in different provinces). In addition, the Gauteng is South Africa's most densely populated province (Statistics South Africa, 2011). A non-probability judgement sample of four campuses was selected from the sampling frame, two of which are traditional universities and two universities of technology. The samples representation of the target population was improved by two being located in the country region and two in the city region.

\subsection{Sampling method}

For the final study, a non-probability convenience sample of 400 students across the four campuses was taken. In order to overcome the limitations associated with convenience samples and ascertain the degree to which the sample is representative of the target population, demographic questions pertaining to age, gender and province of origin were included. Lecturers at each of the four campuses were contacted and requested to ask their students to complete the questionnaire. These lecturers were requested to ensure that the questionnaires were completed strictly on a voluntary basis. Questionnaires were then hand delivered to the lecturers at each of the four campuses.

\subsection{Research instrument}

A self-administered questionnaire was utilised to gather the required data. The scale developed by Ducoffe (1996) was 
used to measure black Generation $Y$ students' attitudes towards Web advertising value on the dimensions of informativeness (seven items), entertainment (five items), irritation (five items) and value (three items). A subscale measuring the perceived credibility of Web advertising (three items) developed by Bracket and Carr (2001) was added to the scale, together with five items designed to measure perceived consumer benefits of Web advertising. The consumer benefits items included helping people become better consumers, helping people make wise purchase decisions (Ducoffe, 1996), increasing the number of brands the people are aware of, increasing people's ability to find brands that best suite their needs and helping people find brands that offer the best value for money. Responses to this scale were measured on a six-point Likert scale ranging from strongly disagree (1) to strongly agree (6).

Two additional scales were included in the questionnaire, both of which were adapted from Wolburg and Pokrywczynski (2001). The first was designed to measure the perceived informativeness of advertisements in different media on a four-point Likert scale ranging from not informative at all (1) to very informative (4). The second was designed to measure the extent to which advertisements in different media are perceived to represent black Generation $Y$ individuals on a six-point Likert scale ranging from strongly agree (1) to strongly disagree (6). The questionnaire included questions pertaining to respondents' demographical information.

The questionnaire was piloted on 45 black Generation $Y$ students registered at a campus not included in the main study. The Web advertising value scale returned an acceptable Cronbach alpha (Malhotra, 2010) of 0.876 for the overall scale, with Cronbach alphas ranging from $a=0.656$ to $a=0.884$ on the individual dimensions. The representation in media scale returned a Cronbach alpha of $a=0.849$.

\subsection{Results}

A relatively high response rate of 65 percent was attained, with 261 completed questionnaires received back from the sample of 400 respondents. Respondents' ages ranged from 18 to 24 years old. Of South Africa's nine provinces, eight were represented, with only the Western Cape not represented. The majority of respondents indicated their province of origin to be Gauteng (37\%), followed by Limpopo (27.0\%). The sample contained an even number of male and female respondents. Table 1 outlines a description of the sample.

Table 1. Sample description

\begin{tabular}{cccclc}
\hline Age & Percent (\%) & Gender & Percent (\%) & Province & Percent (\%) \\
\hline 18 & 12.6 & Male & 50.0 & Eastern Cape & 3.1 \\
19 & 21.3 & Female & 50.0 & Free State & 10.5 \\
20 & 21.3 & & & Gauteng & 37.4 \\
21 & 19.7 & & & KwaZulu-Natal & 5.1 \\
22 & 15.0 & & & Limpopo & 26.8 \\
23 & 5.9 & & Mpumalanga & 5.8 \\
24 & 4.3 & & Northern Cape & 0.8 \\
& & & North West & 1.5 \\
& & & & Western Cape & 0 \\
\hline
\end{tabular}

In the final study, the reliability coefficients for the overall Web advertising value scale and its individual dimensions were in line with the recommended level of $a=0.700$ (Nunally, 1978), with informativeness at $a=0.893$, entertainment at $a=0.904$, irritation at $a=0.866$, value at $a=0.771$, consumer benefits at $a=0.819$ and credibility at $a=0.771$. A Cronbach alpha of $a=0.874$ was computed for the overall Web advertising value scale.

The respondents ranked advertising on the Web as being the third most informative media (Mean=3.46), with television ranked first (Mean=3.65) and radio second (Mean=3.54). Advertising in newspapers was ranked fourth (Mean=3.35), followed by that is magazines (Mean=2.86). Direct mail (Mean=2.73) and billboard/poster advertising $(M e a n=2.70)$ were ranked lowest. The respondents indicated that, in general, black Generation $Y$ were represented in mass media advertising (Mean=3.77). They indicated being the most represented in radio (Mean=3.82), followed by magazines (Mean=3.68), which may reflect a better audience target match for these two media. The means for 
representation in advertising in other media channels were computed as 3.64 for billboards/posters, 3.63 for television, 3.61 for the Web and 3.40 for cinema.

Concerning attitude towards Web advertising value, Means above 3 were computed on the dimensions of informativeness (Mean=4.48), entertainment (Mean=4.25), value (Mean=4.47), consumer benefits (Mean=4.18) and credibility (Mean=3.73). A mean below 3 was recorded on the dimension of irritation (Mean=2.96). A one-tailed z-test was performed to determine whether these computed means are significant. The expected mean was set at 3 and the significance level at the conventional $\alpha=0.05$. Table 2 presents the calculated $z$-scores and $p$-values. P-values of $p<0.05$ were computed on the dimensions of informativeness, entertainment, value, consumer benefits and credibility value indicating each to be statistically significant. The dimension of irritation was not significant $(p=0.2981>0.05)$. This infers that black Generation $Y$ students have a positive perception of Web advertising value and do not find it particularly irritating.

Table 2. Black Generation Y students' attitudes towards Web advertising

\begin{tabular}{lccccc}
\hline & Mean & $\begin{array}{c}\text { Standard } \\
\text { Deviation }\end{array}$ & $\begin{array}{c}\text { Standard } \\
\text { Error }\end{array}$ & z-scores & p-value \\
\hline Informativeness & 4.48 & 1.008 & 0.062 & 23.69 & $0.000^{*}$ \\
Entertainment & 4.25 & 1.131 & 0.070 & 17.79 & $0.000^{*}$ \\
Irritation & 2.96 & 1.210 & 0.075 & -0.53 & 0.2981 \\
Value & 4.47 & 1.022 & 0.063 & 23.22 & $0.000^{*}$ \\
Benefits & 4.18 & 0.991 & 0.061 & 19.31 & $0.000^{*}$ \\
Credibility & 3.73 & 1.134 & 0.070 & 10.43 & $0.000^{*}$ \\
\hline${ }^{*}$ Significant at $p<0.05$ (one-tailed) & & & & \\
\hline
\end{tabular}

In order to determine the relationship between Web advertising value and its five antecedents of informativeness, entertainment, irritation, consumer benefits and credibility, Pearson's Product-Moment correlation coefficient was computed. The results are reported on in Table 3.

Table 3. Relationship between Web advertising value and its antecedents

\begin{tabular}{lcccccc}
\hline & Informative & Entertainment & Irritation & Value & Benefits & Credibility \\
\hline Informative & 1.000 & $.480^{* *}$ & $-.284^{* *}$ & $.621^{* *}$ & $.553^{* *}$ & $.308^{* *}$ \\
Entertainment & $.480^{* *}$ & 1.000 & -.109 & $.393^{* *}$ & $.416^{* *}$ & $.387^{* *}$ \\
Irritation & $-.284^{* *}$ & -0.109 & 1.000 & $-.282^{* *}$ & $-.284^{* *}$ & -0.12 \\
Value & $.621^{* *}$ & $.393^{* *}$ & $-.282^{* *}$ & 1.000 & $.608^{* *}$ & $.399^{* *}$ \\
Benefits & $.553^{* *}$ & $.416^{* *}$ & $-.284^{* *}$ & $.608^{* *}$ & 1.000 & $.562^{* *}$ \\
Credibility & $.308^{* *}$ & $.387^{* *}$ & -.012 & $.399^{* *}$ & $.562^{* *}$ & 1.000 \\
\hline
\end{tabular}

${ }^{*}$ Significant at the $p<0.05$ level (2-tailed)

The correlation between Web advertising value and its five antecedents of informativeness, entertainment, irritation, consumer benefits and credibility are significant and in the expected direction. The relationships between most of the antecedents are significant. However, in a departure from findings in previous studies, the relationships between irritation and entertainment $(r=-0.109, p>0.05)$ and irritation and credibility $(r=-0.012, p>0.05)$, while in the expected direction were not significant.

Regression analysis was undertaken to investigate whether the five antecedents predict black Generation $Y$ students' attitude towards Web advertising value. Table 4 reports on the regression model summary and ANOVA results. 
Table 4. Regression model summary

\begin{tabular}{|c|c|c|c|c|c|c|}
\hline & $\begin{array}{c}\text { Standardised } \\
\text { Beta coefficient }\end{array}$ & $\mathbf{R}^{2}$ & Adjusted R² & $\begin{array}{c}\text { Standard error } \\
\text { of estimate }\end{array}$ & $F$ & $\begin{array}{c}\text { Significance } \\
\text { level }\end{array}$ \\
\hline Model 1 & $0.706^{\star *}$ & 0.498 & 0.488 & 0.731 & 50.619 & 0.000 \\
\hline
\end{tabular}

Looking at the regression model summary and ANOVA results in Table 4, it is evident that the regression is statistical significant indicating that the five Web advertising value antecedents may be used as predictors for the dependent variable of Web advertising value (F-value $=50.619, p=0.000<0.05)$. The coefficient of multiple determination $\left(R^{2}\right)$ was computed as 0.498 , indicating that a respectable 49.8 percent of the variation in black Generation $Y$ students' attitudes towards Web advertising value can be explained by the variance of the five antecedents of informativeness, entertainment, irritation, consumer benefits and credibility.

The next step undertaken was to evaluate the contribution of each of the antecedents to the prediction of attitude towards Web advertising value. The results are reported on in Table 5.

Table 5. Evaluation of contribution of each of the independent variables

\begin{tabular}{|c|c|c|c|c|}
\hline & $\begin{array}{c}\text { Standardised } \\
\text { Beta coefficient }\end{array}$ & Adjusted $\mathrm{R}^{2}$ & t-value & $\begin{array}{c}\text { Significance } \\
\text { level }\end{array}$ \\
\hline \multicolumn{5}{|c|}{ Dependent variable: } \\
\hline \multicolumn{5}{|c|}{ Web advertising value } \\
\hline \multicolumn{5}{|c|}{ Independent variables: } \\
\hline Informative & $0.621^{\text {** }}$ & 0.383 & 12.751 & 0.000 \\
\hline Entertainment & $0.393^{\star *}$ & 0.151 & 6.874 & 0.000 \\
\hline Irritation & $-0.282^{* *}$ & 0.076 & 4.729 & 0.000 \\
\hline Benefits & $0.608^{* *}$ & 0.368 & 12.335 & 0.000 \\
\hline Credibility & $0.399^{* *}$ & 0.156 & 6.994 & 0.000 \\
\hline
\end{tabular}

As shown in Table 4, informativeness ( $\beta=0.621, p=0.000<0.05)$, entertainment $(\beta=0.0393, p=0.000<0.05)$, consumer benefits $(\beta=0.608, p=0.000<0.05)$ and credibility $(\beta=0.399, p=0.000<0.05)$ have a significant positive influence on black Generation $Y$ students' attitudes towards Web advertising value. The irritation antecedent $(\beta=-0.282$, $p=0.000<0.05$ ) has a significant negative influence on black Generation $Y$ students' attitudes towards the value of Web advertising. The largest beta coefficients were recorded on informativeness, followed by consumer benefits, which means that these two antecedents make the strongest contribution to explaining black Generation Y students' attitude towards the value of Web advertising. The irritation antecedent made the smallest contribution.

\section{Discussion}

In South Africa, the black Generation $Y$ cohort represents a significantly sized target market. Those with a tertiary qualification are expected to be of especial marketing significance given that graduates typically have a higher earning potential and social status, thereby rendering them important trendsetters amongst their peers.

The findings of this study suggest that, overall, black Generation $Y$ students have a positive attitude towards the value of Web advertising and that it is a desirable advertising platform for reaching this target market. In terms of the informative value of Web advertising, they ranked it ahead of newspaper, magazine, direct mail and billboard/poster 
advertisements but below that of television and radio advertisements. Given the easy with which content can be added to Web advertisements, marketers should strive to add links to their Web-based advertisements that provide more in-depth information on product features, benefits, prices, customer reviews, FAQs and the like. In certain product categories, such as music and books, it may be valuable to offer test samples. In other categories, such as hotel accommodation, tourist destinations, universities and shopping malls, virtual tours may enhance the informative value of Web advertisements.

While this age and ethnic cohort consider themselves well represented in mass media advertising in general, they ranked their representation in Web-based advertisements the lowest. Marketers targeting the black Generation $Y$ cohort in South Africa using Web advertisements need to take cognisance of this and consider using local black celebrities in their online advertising and/or adding themes tailored to appeal to this market segment.

According to the results of this study, black Generation $Y$ students have a significantly positive attitude towards Web advertising value, as well as towards its individual determinants of informativeness, entertainment, consumer benefits and credibility. Interestingly, their attitude towards the irritation dimension was not significant.

Correlation analysis revealed that, as in the case of previous studies, the relationships between the five antecedents were in the expected direction and, for the most part, significant. However, unlike prior studies, the relationships between irritation and entertainment, and irritation and credibility, while negative, were not significant. This suggests that black Generation $Y$ students do not perceive irritation as a significant detractor from the entertainment and credibility value of Web advertisements.

Using regression analysis, it was determined that the five antecedents of informativeness, entertainment, irritation, consumer benefits and credibility do predict black Generation $Y$ students' attitude towards Web advertising value in the South African market. In terms of the contribution of each antecedent, it was established that the informativeness and consumer benefits dimensions have the strongest influence on black Generation $Y$ students' attitude to the value of Webbased advertisements and irritation the weakest influence. This infers that marketers targeting this target market should focus their efforts on ensuring that their Web advertisements supply in-depth product information and are designed to aid the consumer decision-making process.

In addition, given that most South Africans access the Web via mobile devices, when designing Web advertisements, cognisance should be given to the fact that exposure to these advertisements will occur over mobile devices.

\section{Limitations and future research}

There are several limitations to the study that should be taken into account when interpreting the results. First, convenience sampling was used to gather the required data. Demographic questions concerning age, gender and province of origin were included in an effort to overcome the issue of target population representation inherent with convenience sampling. However, while there was an equal split between the genders, each of the age categories of the target population was covered and eight of South Africa's nine provinces were represented, the sample included no respondents from the Western Cape.

Secondly, the research design followed involved a cross-sectional study, which only offers a snap shot in time. Given the pace at which Web-based advertising is evolving, a longitudinal study would provide a more accurate depiction of black Generation Y students' attitudes of Web advertising value.

A third limitation is that the study looked at Web advertisements in general, rather than specific types of Web advertisements. Future research focusing on specific Web advertisement formats is likely to add important insight into this cohort's attitude towards Web advertising value.

\section{Conclusion}

The Web has become an important advertising platform. Whilst South African Internet usage and online shopping lag behind the rest of the world, there is evidence that this is changing as the country witnesses a rapid uptake of Internetenabled mobile devices. The significantly sized black Generation Y cohort represents a major portion of the country's Internet community. The results of this study suggest that Web-based advertising is a particularly desirable platform for marketers seeking to target this age and ethnic cohort. 


\section{References}

Autry, A.J. \& Berge, Z. (2011). Digital natives and digital immigrants: getting to know each other. Industrial and Commercial Training, 43(7), 460-466.

Avusa Media Live. (2011). Digital milestone achieved as black online audience overtakes white. [Online] Available: http://m.bizcommunity.com/Pressoffice?AvusaMediaLive (22 March 2012).

Bakewell, C. \& Mitchell, V. (2003). Generation Y female consumer decision-making styles. International Journal of Retail and Distribution Management, 31(2), 95-106.

Bakewell, C., Mitchell, V. \& Rothwell, M. (2006). UK Generation Y male fashion consciousness. Journal of Fashion Marketing, 10(2), 169-180.

Bevan-Dye, A, L. \& Surujlal, J. (2011). Attitude towards materialism in sport and materialism trends among black Generation Y students. African Journal for Physical, Health Education, Recreation and Dance, September (Supplement), 43-55.

Blackwell, R.D., Miniard, P.W. \& Engel, J.F. (2006). Consumer behavior (10th ed.) Mason, Ohio: Thomson South-Western.

Boyle, B. (2011). Death of newspaper premature. December 15. [Online] Available: http://www.timeslive.co.za (19 March 2012).

Bracket, L.D. \& Carr, B.N. (2001). Cyberspace advertising vs other media: Mature student attitudes. Journal of Advertising Research, 41(5), 23-32.

Carlson, J. \& O'Cass, A. (2011). Managing web site performance taking account of the contingency role of branding in multichannel retailing. Journal of Consumer Marketing,

28(7), 524-531.

Cheng, J.M., Blankson, C., Wang, E.S. \& Chen, L.S. (2009). Consumer attitudes and interactive digital advertising. International Journal of Advertising, 28(3), 501-525.

De Lanerolle, I. (2012). The New Wave: Who connects to the Internet, how they connect and what they do when they connect. South African Network Society Project. University of Witwatersrand. [Online] Available: http://www.networksociety.co.za. (16 March 2013).

De Waal M (2008). Why aren't South African brands haute? http://www.moneyweb.co.za/mw/view/mw/en/page 215461? oid=215672\&sn=Detail (18 July 2009).

Ducoffe, R.H. (1996). Advertising value and advertising on the Web. Journal of Advertising Research, 36(5), 21-35.

Durvasula, S. \& Lysonski, S. (2008). A double-edged sword: understanding vanity across cultures. Journal of Consumer Marketing, 25(4), 230-244.

EMarketer. (2011). Online advertising market poised to grow $20 \%$ in 2011. [Online] Available: http://www.emarketer.com/Articles Print.aspx?R=1008432 (16 March 2012).

EMarketer. (2013). Digital to account for one in five ad Dollars. [Online] Available: http://www.emarketer.com/Articles/Print aspx?R=1009592 (16 March 2013).

Fairweather, A. 2012. Online shopping in South Africa has (finally) come of age. [Online] Available: http://www.mg.co.za/article/ 2012-11-22-00-online-shopping-in-south-africa-has-finally-come-of-age (16 March 2013).

Foscht, T., Schloffer, J., Maloles, C \& Chia, S.L. (2009). Assessing the outcomes of Generation-Y customers' loyalty. International Journal of Bank Marketing, 27(3), 218-241.

Hurst, J.L. \& Good, L.K. (2009). Generation Y and career choice: the impact of retail career perceptions, expectations and entitlement perceptions. Career Development International, 14(6), 570-593.

Internet World Stats. (2012). World Internet usage and population statistics June 30, 2012. [Online] Available: http://www.internetworldstats.com/stats.htm (12 August 2012).

Jones, G. (2007). Black Diamonds continue to grow. [Online] Available:http://www.marketingweb.co.za. (29 September 2010).

Korgaonkar, P., Silverblatt, R. \& O'Leary, B. (2001). Web advertising and Hispanics. Journal of Consumer Marketing, 18(2), 134152.

Kotler, P. (2003). Marketing management (11th ed.). New Jersey: Prentice Hall.

Loudon, D.L. \& Della Bitta, A.J. (1993). Consumer behavior: concepts and applications (4th ed.). New York: McGraw-Hill.

Kumar, A. \& Lim, H. (2008). Age differences in mobile service perceptions: comparison of Generation Y and baby boomers. Journal of Services Marketing, 22(7), 568-577.

Maake, M. (2012). Vast numbers of mobile users presenting big opportunities. Sunday Times: Business Times, March 11, p. 7.

Magnaglobal. (2013). Magnaglobal advertising forecast 2013. Magnaglobal. [Online] Available: http://www.magnaglobal.com. (16 March 2013).

Malhotra N.K.(2010). Marketing Research: An Applied Orientation (6th ed.) Upper Saddle River, NJ, USA: Pearson Prentice Hall.

Markert, J. (2004). Demographics of age: generational and cohort confusion. Journal of Current Issues and Research in Advertising, 26(2), 11-25

Masote, M. (2012). Tablet users hungry for data. Sunday Times: Business Times, March 11, p. 7.

Mowen, J.C. (1993). Consumer Behavior (3rd ed.). New York: Macmillan Publishing Company. 
Mzekandaba, S. 2012. South Africa is slow to adopt online shopping. IT Web Africa. August 7. [Online] Available: http://www.itwebafrica.com/internet/238-south-africa/229774-south-africa-is-slow-yo-adopt-online-shopping (15 March 2013).

Newborne, N. \& Kerwin, K. (1999). Generation Y. Business Week, February 15, p. 80-8.

Nicholas, D., Rowlands, I., Clark, D. \& Williams, P. (2011). Google generation II: web behaviour experiments with the BBC. Aslib Proceedings: New Information Perspectives, 63(1), 28-45.

Nunally, J.C. (1978). Psychometric theory (2nd ed.). New York: McGraw-Hill.

Olivier, D. (2007). South Africa poised to become a loyalty marketing gem. Journal of Consumer Marketing, 24(3), 180-181.

Pollay, R.W. \& Mittal, B. (1993). Here's the beef: factors, determinants and segments in consumer criticism of advertising. Journal of Advertising, 57(3). 99-113.

Prendergast, G., Liu, P. \& Poon, D.T.Y. (2009). A Hong Kong study of advertising credibility. Journal of Consumer Marketing, 26(5), 320-329.

Rahman, S. \& Azhar, S. (2011). Xpressions of generation Y: perceptions of the mobile phone service industry in Pakistan, Asia Pacific Journal of Marketing and Logistics, 23(1), 91-107.

Schiffman, L.G., Kanuk, L.L. \& Wisenblit, J. (2010). Consumer behavior (10th ed.). New Jersey: Pearson Prentice Hall.

Schwalbe, C.B. (2009). Leveraging the digital media habits of the Millennials: strategies for teaching journalism courses. South Western Mass Communication Journal, 25(Fall), 53-68.

Shaw, S. \& Fairhurst, D. (2008). Engaging a new generation of graduates. Education + Training, 50(5), 366-378.

Shevel, A. (2011). Black people rise in earnings stakes. Sunday Times: Business Times, October 2, p. 1.

Spero, I. \& Stone, M. (2004). Agents of change: how young consumers are changing the world of marketing. Qualitative Market Research: An International Journal, 7(2), 153-159.

Statistics South Africa. (2011). Mid-year population estimates: 2011. Key indicators, Statistical release P0302. [Online] Available: http://www.statssa.gov.za. 27 August 2011.

Taskinsoy, J. (2012). The return of investment on tertiary education in Malaysia. Journal of Education and Vocational Research, 3 (6), 183-192.

Tayler, D.G., Lewin, J.E. \& Strutton, D. (2011). Friends, fans and followers: do ads work on social networks? How gender and age shape receptivity. Journal of Advertising Research, 51(1), 258-275.

Twenge, J.M. \& Cambell, S.M. (2008). Generational differences in psychological traits and their impact on the workplace. Journal of Managerial Psychology, 23(8), 862-877.

Wang, Y., Sun, S., Lei, W. \& Toncar, M. (2009). Examining the beliefs and attitudes towards online advertising among Chinese consumers. Direct Marketing: An International Journal, 3(1), 52-66.

Wang, Y. \& Sun, S. (2010). Examining the role of beliefs and attitudes in online advertising: a comparison between the USA and Romania. International Marketing Review, 27(1), 87-106.

Wolburg, J.M. \& Pokrywczynski, J. (2001). A psychographic analysis of Generation Y college students. Journal of Advertising Research, September/October, 33-52.

Wolin, L.D. \& Korgaonkar, P. (2003). Web advertising: gender differences in beliefs, attitudes and behavior. Internet Research: Electronic Networking Applications and Policy, 13(5), 375-385.

Wu, S., Lin, C.S. \& Lin, J. (2011). An empirical investigation of online users' keyword ads search behaviours. Online Information review, 35(2), 177-193. 